\title{
ОТНОСИТЕЛЬНАЯ ХРОНОЛОГИЯ И ПЕРИОДИЗАЦИЯ СИНТАШТИНСКИХ ПОГРЕБАЛЬНЫХ ПАМЯТНИКОВ ЗАПАДНОГО КАЗАХСТАНА В БАССЕЙНЕ РЕКИ ИЛЕК
}

\author{
(C) 2019 г. А.И. Хаванский
}

\begin{abstract}
В статье рассматриваются результаты построения относительной хронологии и периодизации погребений синташтинской культуры Западного Казахстана в бассейне реки Илек. Автором были выделены три хронологических периода и дана характеристика каждого периода. Используя соотношение различных видов орнамента в каждом погребении (закрытом комплексе), удалось построить относительную хронологию и выявить периоды в развитии синташтинских традиций в области погребального обряда, типологии металлических изделий (прежде всего ножей-кинжалов), традиций формообразования и орнаментации керамики. Выявлены долговременные тренды и маркеры отдельных периодов. В Период 1 синташтинские группы населения появляются в данном регионе и существуют относительно обособленно от других этнокультурных групп. Набор керамики, металлических изделий, украшений достаточно компактен, традиции относительно однородны. В Период 2 начинаются контакты с инокультурным, вероятно, с раннеалакульским (срубноалакульским?) населением. Это проявляется в появлении керамики с алакульскими чертами (горшков с вогнутым плечом (уступом), резком увеличении доли узоров из треугольников и лент, разнообразии видов женских украшений, появлении некоторых типов ножейкинжалов). В Период 3 продолжаются те же тенденции, что в Период 2. Нужно подчеркнуть, что ядро синташтинских традиций сохраняется на протяжении всей истории существования синташтинской группы населения в Западном Казахстане и культурные контакты с ранними алакульцами только ускорили развитие технологий и культурных традиций.
\end{abstract}

Ключевые слова: археология, синташтинская культура, периодизация, погребальный обряд, кинжалы, керамика, орнамент, культурные традиции

Синташтинская культура (XXXVIII вв. до н.э.) ассоциируется, в первую очередь, с памятниками, расположенными в Зауралье. Это известное поселение Аркаим, Синташтинский могильник и т.д. Однако и в Казахстане выявлена серия ярких синташтинских могильников: Танаберген II, Бестамак, Халвай III и др. [Ткачев, 2007; Калиева, Логвин В.Н., 2008; Шевнина, Логвин А.В., 2015]. В данной работе речь пойдет о тех из них, которые расположены в бассей- не реки Илек (рис. 1). В.В. Ткачевым эти памятники были обозначены как синташтинская культура степного Приуралья. Им же была сделана попытка провести периодизацию синташтинских памятников данного региона [Ткачев, 2007].

Однако развитие археологической науки, появление новых археологических методов анализа материала позволяет по-новому взглянуть на вопрос территориальной группировки и периодизации данных памятни- 


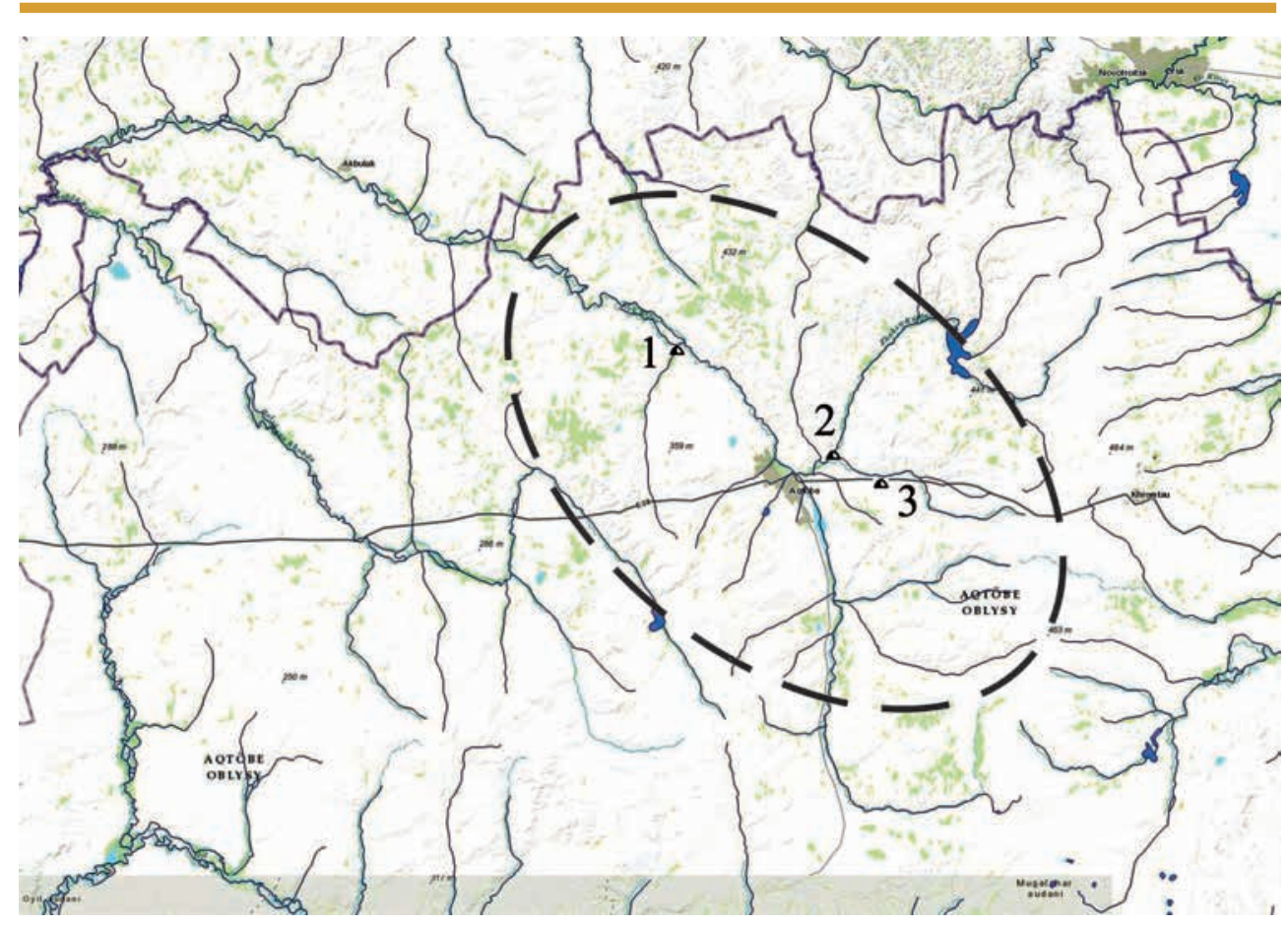

Рис. 1. Карта памятников синташтинской культуры Западного Казахстана (Илекская группа). 1 -мог. Танаберген II; 2 -мог. Жаман-Каргала I; 3 -мог. Красносельский

Fig. 1. Map of Sintashta culture monuments of Western Kazakhstan (Ilek group). 1 - Tanabergen II cemetery; 2 - burial ground of Jaman-Kargala I; 3 - Krasnoselsky cemetery

ков. В статье обосновывается выделение синташтинских могильников на р. Илек в отдельную группу и предлагается их новая периодизация.

Начнем с территориальной группировки. В.В. Ткачевым в одну территориальную группу были объединены могильники Танаберген II, Жаман-Каргала I, Герасимовка II, Новокумакский, Ишкиновка I, II [Ткачев, 2007, с. 16-17, рис. 1]. Автором не приводится обоснований, по какой причине в одну группу были сведены памятники, относящиеся к бассейнам двух рек (Урала и Илека). Далее, от могильника Танаберген II до Новокумакского могильника расстояние составляет 150 км, а до могильника Герасимовка II - 280 км. По этой причине сомнительно, что население, оставившее эти могильники, было действительно единым. Методически оправданным будет выделение группы памятников, которые, находясь на относительно небольшом расстоянии друг от друга, располагались бы в бассейне одной реки. В этом случае можно предполагать реальные родственные отношения этого населения. Согласно этим принципам, могильники Танаберген II, Жаман-Каргала I и Красносельский [раскопки А.А. Бисембаева, материал готовится к публикации - прим. авт.], которые компактно расположены в среднем течении р. Илек, могут быть объединены в Илекскую группу синташтинской культуры (рис. 1). 
Хаванский А.И. Относительная хронология и периодизация синташтинских...

Далее, перейдем к периодизации. В.В. Ткачев в приуральской группе синташтинской культуры выделяет два этапа: к первому этапу относится могильник Танаберген II, ко второму - все остальные могильники [Ткачев, 2007, с. 312-321]. Основания, по которым проведено такое деление, автором не приводится, вероятно, в основе лежала интуиция исследователя. Между тем, расстояние между могильниками Герасимовка II и Новокумакский составляет 280 км, в то время как с методической точки зрения хронологическому членению подлежат памятники, находящиеся в одном микрорайоне или хотя бы регионе. Поэтому, различия между памятниками могут носить не хронологический, а территориальный характер. Более того, автор не учитывает возможности частичной синхронности функционирования могильников.

\section{Методика}

В данном исследовании периодизация и внутренняя относительная хронология Илекской группы синташтинской культуры строится на основании методики Ю.Б. Цетлина [Цетлин, 2008, с. 15-18]. Эта методика с корректировкой, применительно к погребальным памятникам была успешно использована в исследованиях, посвящённых памятникам Южного Урала и Западного Казахстана эпохи поздней бронзы [Хаванский, 2010a; 2010б; 2016].

Хотя для построения хронологии в качестве основы была выбрана методика Ю.Б. Цетлина, однако в силу того, что она разрабатывалась и применялась для поселенческой керамики, в нее пришлось внести определенные коррективы. Во-первых, в качестве минимальной единицы хронологии выступает погребение (закрытый комплекс) (а не пласт культурно- го слоя). Во-вторых, особое внимание уделяется расположению мотивов на различных частях сосудов (на неолитической керамике это было трудно сделать как в силу фрагментированности поселенческого материала, так и в силу простоты формы неолитических сосудов).

Первоначально была предпринята попытка традиционно рассматривать каждый отдельный могильник как некое целостное культурное явление и на этой основе построить их относительную хронологию. Для этого были изучены состав и соотношение различных орнаментов на сосудах отдельно из каждого могильника, затем проведен сравнительный анализ всех могильников по этому признаку и, наконец, осуществлена их относительная хронологизация на основании данных о степени сходства могильников друг с другом по составу и соотношению элементов орнамента. В результате этого была получена картина, которая сильно противоречила как данным стратиграфии и радиоуглеродного анализа памятников, так и сложившимся к настоящему времени представлениям исследователей о культурном развитии Западного Казахстана в начале поздней бронзы. Выявленные противоречия заставили несколько по-иному подойти к решению проблемы периодизации керамических комплексов. Была предпринята попытка реконструировать относительную хронологию керамических комплексов не по отдельным могильникам, а по погребениям с керамикой в рамках каждого могильника. В основу такого подхода были положены представления о том, что, во-первых, каждый могильник мог функционировать какое-то достаточно продолжительное время, по крайней мере, несколько поколений, 
во-вторых, могильники одной культуры, расположенные на разных территориях, могли по времени в той или иной степени сосуществовать друг с другом.

В соответствии с этим подходом к построению относительной хронологии комплексов, сначала нужно было установить относительную хронологию погребений в каждом могильнике, а потом уже эти могильники синхронизировать между собой.

Для построения относительной хронологии по погребениям необходимо выяснить вопрос о возможности рассматривать синташтинские погребения как закрытые комплексы. Для этого мы имеем следующие данные:

1) совместное захоронение нескольких погребенных в одной могиле, что, скорее всего, обусловлено единовременностью их смерти. Коллективные захоронения совершены только в крупных могильных ямах;

2) отсутствуют факты, указывающие на отодвигание костей предыдущего умершего и его инвентаря с целью захоронения следующего, что часто встречается в других культурах, где практикуется погребение в склепах;

3) численность погребенных соответствует размерам могильной ямы.

А.В. Епимахов, детально проанализировавший синташтинскую погребальную обрядность, пришел к выводу, что «нет достоверных фактов функционирования склепов» [Епимахов, 2002, с. 44]. На этом основании синташтинские погребения возможно рассматривать как закрытые комплексы.

Для большей надежности результатов при построении относительной хронологии использованы только те погребения, в которых было два или более сосуда. Эти погребения составляют группу т.н. «базовых» погребений. Те погребения, в которых был найден только один сосуд (группа «дополнительных» погребений), из анализа, однако, не исключаются. Они вводятся в него позднее, когда уже реконструирована относительная хронология могильника по группе «базовых» погребений. Принадлежность каждого погребения «дополнительной» группы к определенному периоду выяснялась путем определения степени сходства керамики в нем по составу и соотношению элементов орнамента с керамикой каждого «базового» погребения. Полученный вывод проверялся путем сравнения качественных особенностей орнамента по узорам, мотивам и композициям, а также по форме сосудов.

Такой подход к построению относительной хронологии позволял, во-первых, получить вполне надежные данные об относительной хронологии керамических комплексов и, соответственно, содержащих их погребений по каждому могильнику, во-вторых, синхронизировать разные могильники друг с другом, в-третьих, осуществить «привязку» к реконструированной относительной хронологии «базовых» погребений тех погребений, которые содержали только по одному сосуду.

Конкретная методика построения относительной хронологии керамических комплексов погребений в могильнике включает следующие несколько ступеней. Для наглядности проиллюстрируем этот процесс (рис. 2).

Ступень I. Построение локальной внутренней периодизации отдельного могильника.

I.1. Расчет в процентах доли встречаемости каждого элемента ор- 
Хаванский А.И. Относительная хронология и периодизация синташтинских...

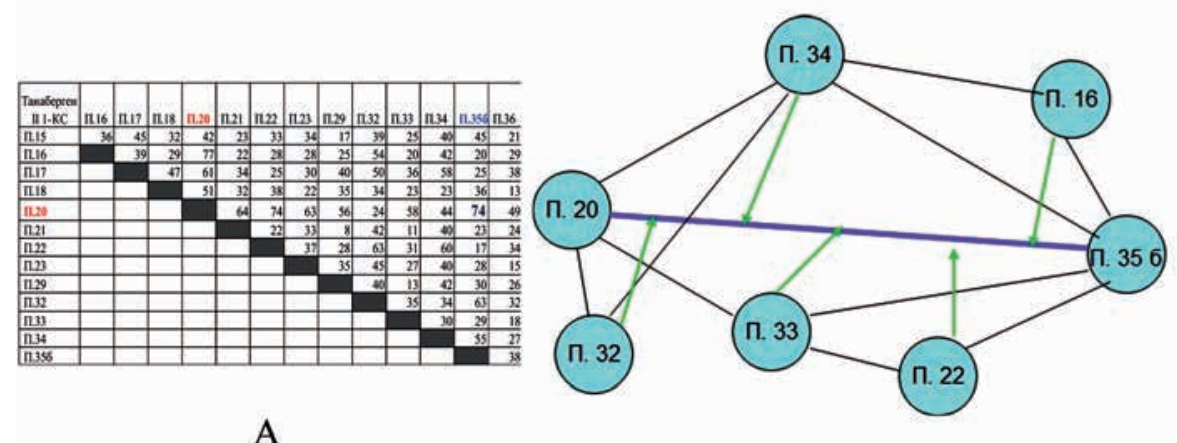

A

Б

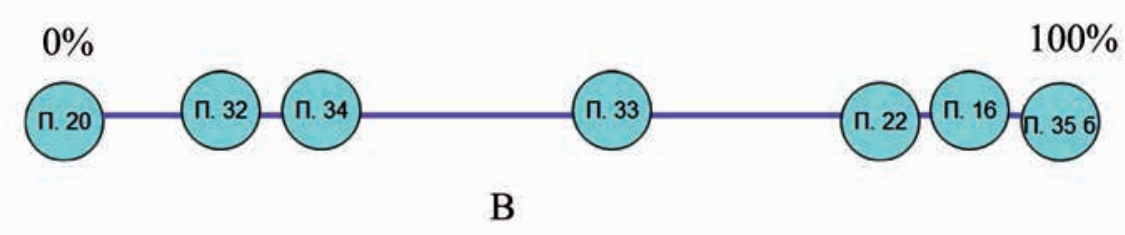

Рис. 2. Схема построения относительной хронологии погребений по различным видам орнамента: A - таблииа коэффиииентов расстояний; Б - график связей между погребениями по коэффициентам; $B$ - проекция погребений на условную хронологическую ось

Fig. 2. The scheme for constructing the relative chronology of burials for various types

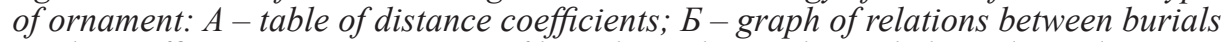

by coefficients; $B$ - projection of burials on the conditional chronological axis

намента в одном закрытом комплексе (погребении) от общего числа случаев, в которых были встречены все элементы орнамента в данном погребении.

I.2. Определение коэффициента сходства (КС) между погребениями данного могильника по составу и процентному соотношению элементов орнамента на сосудах вычисляется по формуле КС=Kmin+Mmin+... +Nmin. Минимальное значение КС может быть равно 0, а максимальное - 100\% [Телегин, 1977]. При этом сам автор высчитывал долю каждой орнаментальной традиции исходя из количества сосудов. Однако им было не учтено, что при нахождении на одном сосуде нескольких элементов орнамента сумма всех долей разных типов орнамента на керамике будет превышать 100\%. Как показали наблюдения Ю.Б. Цетлина, более удобным является анализ, исходящий из общего числа случаев встречаемости проявлений данной конкретной традиции [Цетлин, 2008, с. 16]. В данном случае используется величина, противоположная КС (или 1-КС), которую можно назвать коэффициентом удаленности (или расстояния между разными погребениями) [Цетлин, 2008, c. 16]. Поэтому при определении места погребения на условной оси времени в данной работе использовалось значение 1-КС.

I.3. Определение «места» каждого погребения на условной оси времени среди других погребений данного могильника. 
I.3а. Выделение на условной оси времени ее начала и конца. Те погребения, которые имеют между собой наибольшее расстояние по сходству, находятся на противоположных концах условной хронологической оси.

І.3б. Определение «коэффициента места» каждого погребения на условной хронологической оси (КМ). Коэффициент вычисляется по формуле: $X=[(a 2-b 2+c 2): 2 c 2] \times 100$ [Цетлин, 2008 , с. 17], где «а» - расстояние от исследуемого погребения до начала оси времени (самого раннего погребения), «b» - расстояние от исследуемого погребения до конца оси времени (самого позднего погребения), «с» - длина самой оси времени, «Х»расстояние по времени от начала оси до данного погребения, выраженное в процентах от длины данной условной оси времени.

I.4. Выделение хронологических этапов в рамках могильника. Поскольку разные погребения располагаются на условной оси времени не равномерно, а группами, в качестве отдельного хронологического этапа рассматривается группа таких компактно расположенных погребений, отделенная от другой такой же группы промежутком в 5\% и более. Данный численный порог является условным и введен в качестве «рабочего» до тех пор, пока не выявлены более объективные критерии для выделения разных временных отрезков.

Ступень II. Построение общей периодизации для нескольких могильников.

II.1. Определение коэффициента удаленности (1-КС) между всеми погребениями двух сравниваемых могильников.

II.2. Выбор из всей совокупности результатов нескольких погре- бений, которые относятся к разным могильникам и имеют между собой минимальное расстояние (1-КС) по сходству, указывающее, скорее всего, на то, что данные погребения в обоих могильниках были близки по времени.

II.3. Синхронизация хронологических осей сравниваемых могильников по этим погребениям между собой. При этом более короткая хронологическая ось приводится к масштабу более длинной оси, после чего пересчитывается относительноеположение каждого погребения на общей условной оси времени. В результате получается общая хронологическая ось, показывающая наиболее вероятную относительную последовательность сооружения погребений во всех исследованных могильниках.

Теперь еще раз нужно вернуться к описанию процедуры разделения этой общей последовательности погребений во времени на отдельные хронологические периоды. Этот вопрос уже обсуждался раньше, но тогда речь шла о методе выделения разных этапов в истории функционирования конкретного могильника. Теперь же стоит задача выделения более общих периодов отдельно для различных регионов (территориальных групп памятников). Ввиду того, что эти периоды будут отражать развитие историко-культурных процессов в этих достаточно обширных регионах, они по своему содержанию будут более условны, чем этапы, отражавшие историю каждого из могильников. Для того чтобы выделить периоды развития историко-культурных процессов в регионах, необходимо рассмотреть, как распределяются погребения всех могильников данного региона на условной хронологической оси. Чтобы группы погребений были 
Хаванский А.И. Относительная хронология и периодизация синташтинских...

выделены более объективно, используется метод построения гистограмм [Каменецкий, Узянов, 1977]. «Пики» на гистограмме показывают группы погребений и, следовательно, периоды. Если таким образом периоды не выявляются, однако необходимо показать динамику развития орнамента, то можно выделить условные периоды по тем границам, которые дает гистограмма. Так выделяются хронологические отрезки в рамках одной культурной традиции.

В настоящее время считается доказанным, что культурные традиции в гончарстве (в том числе, культурные традиции создания форм сосудов с определенными очертаниями и культурные традиции создания орнамента на сосудах, выраженные в элементах, узорах, мотивах и композициях) характеризуются значительной устойчивостью в условиях относительно стабильного существования. Изменения этих традиций обусловлены культурными контактами между разными группами древнего населения [Бобринский, 1978; Волкова, 1996; Цетлин, 2008; 2012]. Поэтому оценивая в количественной форме степень близости культурных традиций в формах и орнаментации сосудов по разным памятникам, регионам и хронологическим периодам, мы получаем конкретную информацию о степени культурной близости самих носителей этих традиций и о тенденциях изменения этой культурной близости в пространстве и во времени.

\section{Результаты исследования}

В результате построения относительной хронологии по погребениям было выявлено, что в целом могильники Танаберген II и ЖаманКаргала I функционировали одновременно (рис. 3). В могильнике Танаберген II выделено семь локальных этапов, в которые совершались за- хоронения. Эти этапы маркируются группами погребений на условной оси времени. В могильнике ЖаманКаргала I выделяются два локальных этапа.

На основе распределения погребений 1-й и 2-й локальные этапы могильника Танаберген II и 1-й локальный этап могильника ЖаманКаргала I были объединены в Период 1. К Периоду 2 относятся 3-й, 4-й, 5-й локальные этапы могильника Танаберген II и 2-й локальный этап могильника Жаман-Каргала I были объединены в Период 2. Период 3 составляют 6-й и 7-й локальные этапы могильника Танаберген II. Периоды отделяются друг от друга «пустыми» промежутками, когда погребения в могильниках не совершались.

\section{Проверка результатов}

В кургане 7 могильника Танаберген II имеется несколько случаев стратиграфии, когда одни синташтинские погребения перекрывают другие синташтинские же. Проверим, насколько результаты стратиграфии согласуются с результатами построения внутренней относительной хронологии.

Погребение 16 перекрывало размещавшиеся торцами друг к другу погребения 17 и 18 [Ткачев, 2007, c. 19]. Соответственно, погребение 16 было совершено позже погребений 17 и 18. По результатам построения внутренней хронологии погребение 18 было совершено в момент времени $59 \%$ от начала совершения погребения в могильнике, а погребение 17 находится на отметке $71 \%$ на условной оси времени. Оба эти погребения относятся к Периоду 2. В то же время погребение 16 находится на отметке $87 \%$ от начала совершения погребений в могильнике и относится к Периоду 3. То есть, оно находится на условной оси времени позже, чем по- 


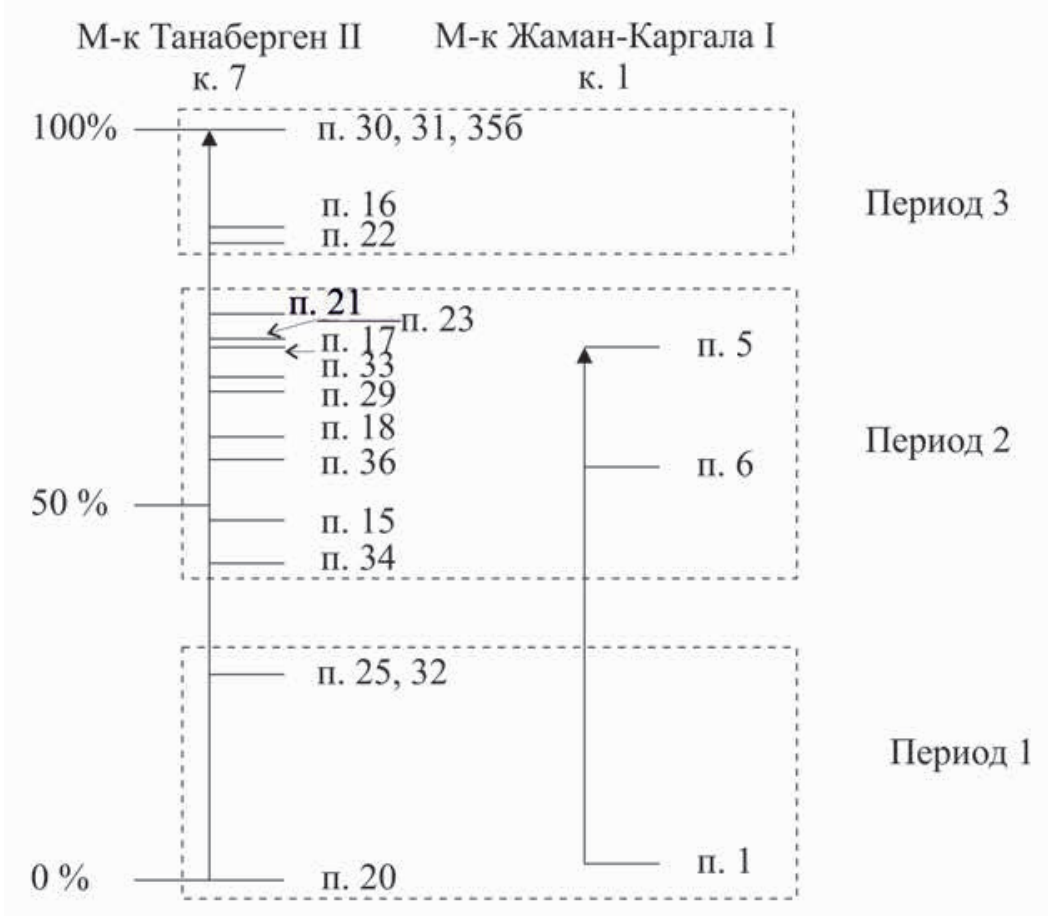

Рис. 3. Относительная хронология погребений могильников Танаберген II и Жаман-Каргала I и хронологические периоды истории могильников

Fig. 3. Relative chronology of the burials of the Tanabergen II and Jaman-Kargala I burials and the chronological periods of the burial grounds

гребения 17 и 18. Это полностью согласуется с данными стратиграфии.

Далее, юго-восточный угол погребения 29 частично прорезался погребением 30 [Ткачев, 2007, с. 35]. По результатам построения относительной хронологии по различным видам орнаментов погребение 29 находится на условной оси времени на отметке 65\% (Период 2), а погребение 30 - на отметке 100\% (оно относится к группе последних захоронений в кургане, Период 3). То есть и здесь данные стратиграфии полностью согласуются с построенной хронологической шкалой.

\section{Анализ результатов}

Детальный типологический анализ погребального обряда и инвентаря могильников Танаберген II и
Жаман-Каргала I уже был проведен [Ткачев, 2007, с. 73-204], поэтому общая характеристика и анализ этих памятников здесь даваться не будет. За основу также была взята типология инвентаря (кроме керамики) вышеупомянутого автора. Обратимся непосредственно к хронологическому анализу.

Период 1 (от 0 до 11\%) (рис. 3; 4, 1-11).

В этот период в могильнике Танаберген II были совершены погребения 20, 25 и 32. Это самые ранние погребения синташтинской культуры Западного Казахстана. Погребение 20 находится в южной поле кургана, а погребения 32 и 25 - в северной [Ткачев, 2007, с. 18, рис. 2]. Можно предположить, что эти погребения марки- 
ровали некую меридиональную ось погребальной площадки. Все погребения Периода 1 одиночные. Более того, они имеют не очень большие для синташты размеры: средняя длина составляет 1,74 м, ширина $0,65 \mathrm{M}$, а глубина - 1,51 м. Также все они довольно скромные по конструкции: погребение 25 совершено в подбое, два погребения имеют ступени на стенках. Каких-либо следов ритуальных действий в виде мела, угольков или пр. в могилах не зафиксировано.

Специфичен половозрастной состав. Это ребенок до 7 лет, женщина 15-20 лет и взрослый мужчина 35-55 лет [Ткачев, 2007, с. 19-39, антропологические определения А.А. Хохлова] (при средней продолжительности жизни синташтинского взрослого населения в 35,5 лет [Рыкушина, 2003, c. 359]). Таким образом, группа населения, оставившая погребения Периода 1, скорее всего, состояла из взрослых людей 20-35 лет, не обремененных детьми. В Период 1 были погребены только ребенок, вероятно, родившийся на новом месте, молодая женщина и зрелый мужчина. Основные силы группы были направлены на освоение нового места жительства, поэтому на погребальный обряд тратилось не так много усилий.

Bce погребенные имеют стандартную позу: скорченно на левом боку. Ориентировка тоже единообразна: на запад или юго-запад. Состав инвентаря не отличается от типичного синташтинского: это глиняные сосуды, бронзовые ножи, плоские тесла, шила; каменные песты, молоты, наковальни и наконечники стрел. Украшения представлены бронзовой подвеской в 1,5 оборота и небольшим количеством фаянсового бисера.

Отдельно остановимся на двух массовых и диагностирующих категориях инвентаря: бронзовых но- жах и глиняной посуде. В Периоде 1 встречаются типичные синташтинские ножи-кинжалы с намечающимся перекрестьем и ромбической пяткой черенка (рис. 6) (Тип 1-1 по В.В. Ткачеву [2007, с. 182-184] - 2 экз. Вероятно, эту форму можно считать общеабашевской. Также встречены ножи с выемкой в месте сочленения лезвия и черенка (Тип 2) [Ткачев, 2007, с. 183184].

Глиняная посуда (рис. 5; 7-10). Для синташтинской керамики этого периода характерен небольшой набор форм: это типичные синташтинские горшки с прямым плечом и внутренним ребром на отгибе венчика (Группа 1) (75\%), миниатюрные сосудики с ребристым профилем (Группа 5) $-13 \%$ и банки - $12 \%$. Посуда в этот период украшалась в основном с помощью гладких и накольчатых элементов, а также налепных шишечек. Из элементов складывались узоры, также ограниченного набора: линейные узоры (в виде зигзага или наклонных линий) - 60\% от всех узоров, треугольные и меандровидные узоры (по 10\%). В мотивах орнамента, которые представляют собой способ распространения элементов и узоров по поверхности сосуда, преобладали простые мотивы из элементов (72\%), то есть посуда этого периода производила впечатления «простой», «бедно» украшенной. На долю мотивов из узоров приходится 23\%; сложные мотивы (из разных элементов и узоров) составляли около $5 \%$.

Таким образом, население, оставившее погребения Периода 1, было монолитным в культурном плане, с устойчивым набором традиций в области погребального обряда и изготовления вещей. 12-41).

Период 2 (25-52\%) (рис. 3; 4,

В этот период совершена основная масса погребений могильника Та- 
наберген II и Жаман-Каргала I (рис. 3). Сопоставление данных планиграфии, стратиграфии и результатов построения относительной хронологии погребений по различным видам орнамента позволяют предполагать, что в этот период сначала были совершены погребение 34 (пристроено с севера к погребению 32 ) и погребения 15,36 (пристроены с севера к погребению 20) [Ткачев, 2007, с. 18, рис. 2]. Таким образом, выстраивалась линия из погребений $20,15,36,32,34$, что находит аналогии в абашевском погребальном обряде. Затем совершаются погребения 18 и 29 (оформляется кольцо) и погребение 33 - заполняется центр. В конце Периода 2 практически синхронно совершаются погребения 21 и 23, которые практически стыкуются друг с другом длинными сторонами.

В этот период размеры могильных ям существенно увеличиваются: средняя длина составляет уже 2,35 м, ширина $-1,68$, а глубина $-2,31$ (более чем в 1,5 раза!). Наравне с одиночными погребениями встречаются парные и коллективные. Внутримогильных конструкций становится больше: $70 \%$ погребений имеют деревянное перекрытие и ступеньки в стенках ямы, $30 \%$ ям имеют пазы в стенках, куда закладывались доски перекрытия. В этот период фиксируют следы многочисленных ритуальных действий в могиле: отмечены следы кострищ и угольки, кусочки мела и посыпка дна песком.

Изменяется половозрастное соотношение. Доля мужчин достигает $44 \%$, они как взрослого, так и возмужалого возраста. Доля женщин -38\%, в основном взрослые (20-35 лет). Погребенных детей немного (только $18 \%$ ), но эта аномалия характерна в целом для синташтинской культуры. В позе скорченно на левом боку захо- ронены 74\% погребенных. В остальных случаях наблюдается большое разнообразие: скорченно и вытянуто на спине, скорченно на правом боку. В ориентировке головой преобладает юго-западное направление (52\%), остальные случаи достаточно равномерно занимают все сектора, кроме северного (не встречается вообще). В женских погребениях появляется большое количество украшений. Из металлических - это подвески в 1,5 оборота, широкожелобчатые браслеты, бляшки и пронизи. Отмечены каменные бусы и большое количество разнообразного фаянсового бисера. Встречены и предметы, которые можно отнести к ритуальным: разноцветные камни, куски мела, раковины и альчики. Бронзовые широкожелобчатые браслеты, подвески в 1,5 оборота и фаянсовый бисер широко встречаются в алакульской культуре [Усманова, 2005, с. 217 , рис. $76,1-20$; с. 210-212, рис. 69-71].

Среди бронзовых ножей, как и в Период 1, чаще всего встречаются ножи-кинжалы общеабашевской формы - с намечающимся перекрестьем и ромбической пяткой черенка (тип 1-1 по В.В. Ткачеву). Отмечен в этот период и небольшой ножичек с выемкой в месте стыковки лезвия и черенка (тип 2 по В.В. Ткачеву).

Надежными хронологическими реперами данного периода являются два типа ножей-кинжалов, которые встречены только в Периоде 2 и более не встречаются (рис. 4, 23, 30, 33; 6). Один тип - это ножи-кинжалы с намечающимся перекрестьем и округлым окончанием черенка, лезвие имеет ромбическое или линзовидное сечение (тип 1-3 по В.В. Ткачеву). Они найдены в погребениях 23 и 33 кургана 7 могильника Танаберген II и в погребении 5 кургана 1 могильника 
Хаванский А.И. Относительная хронология и периодизация синташтинских...

Жаман-Каргала I [Ткачев, 2007, с. 32, рис. 10 ; с. 42 , рис. 17,3 ; с. 53 , рис. 25 , 16]. Скорее всего, они являются упрощенной версией типа 1-1.

Второй тип ножей-кинжалов, который встречается только в Периоде 2, - это ножи без перекрестия с удлиненным лезвием, края лезвия зачастую параллельны, окончание черенка округлое (тип 3-2 по В.В. Ткачеву).

Отметим интересный факт: ножи-кинжалы типа 1-3 всегда встречаются в паре с ножами-кинжалами типа 1-1 (погребения 23 и 33 мог. Танаберген II, к. 7; п. 5 мог. ЖаманКаргала I, к. 1). Тип 3-2 встречается в паре с типом 1-1 только в двух случаях из четырех (мог. Танаберген II, к. 7, п. 21; мог. Жаман-Каргала I, к. 1, П. 5).

Глиняная посуда (рис. 5; 7-10). В Период 2 доля типично синташтинской формы - горшки с ребристым профилем, прямым плечом и внутренним ребром на отгибе венчика уменьшается до $47 \%$, появляются горшки с плавным профилем (26\%), a доля миниатюрных горшочков с ребристым профилем остается неизменной $-12 \%$. В то же время появляются совершенно новые формы: это горшки с ребристым профилем и вогнутым плечом (Группа 4) (2\%). Они находят аналогии в алакульской керамике. Появляются «гибридные» формы синташтинской и алакульской керамики, когда на горшке с ребристым профилем и прямым плечом отсутствует внутреннее ребро (Группа 2) и наоборот: на горшке с ребристым профилем и вогнутым плечом внутренне ребро есть (Группа 3) - по $2 \%$ каждый. Это свидетельствует о контактах синташтинского населения с алакульским и заимствовании новой формы.
В области орнамента для этого периода происходят следующие изменения. Доля линейных узоров резко уменьшается до $26 \%$ (более чем в 2 раза) по сравнению с Периодом 1 , доля треугольных узоров, наоборот, увеличивается в 2 раза до $22 \%$. Доля меандровидных узоров остается практически прежней - 8\%. В данном периоде впервые появляются ромбические и крестообразные узоры, а также узоры в виде волны и в виде лент. На уровне мотивов доля простых мотивов из элементов уменьшается до $56 \%$, а простых мотивов из узоров увеличивается до $37 \%$, как и доля сложных мотивов из разных элементов и узоров (7\%). Обобщая произошедшие изменения в области керамики можно сделать вывод, что синташтинская керамика становится более «нарядной», а ее стилистика более разнообразной. Увеличение доли треугольных узоров можно связать с контактами с алакульским населением, для которого характерна высокая доля треугольных узоров в орнаментации керамики.

Таким образом, в Период 2 происходят контакты синташтинского населения с инокультурным окружением. В результате у синташтинского населения появляются новые типы ножей-кинжалов, глиняной посуды, меняется орнаментальная стилистика глиняной посуды. Получают распространение новые формы женских украшений. Можно предположить, что в основной своей массе инокультурное окружение было представлено группами алакульского населения Западного Казахстана на ранних этапах своей истории. 42-54).

Период 3 (61-74\%) (рис. 3; 4,

В этот период совершаются последние захоронения в могильнике Танаберген II. Размеры могильных ям 
незначительно уменьшаются: средняя длина составляет 2,04 м, ширина 1,56 м, глубина - 1,86 м. Могильные ямы только индивидуальные, в качестве внутримогильных конструкций используются ступень и деревянные камеры. Изменяется половозрастной состав. Среди погребенных только один мужчина в возрасте 35-55 лет, доля женщин - более $30 \%$, большинство из них также 35-55 лет. Остальные погребенные - дети и подростки до 15 лет. Совершенно нет индивидов 15-20 лет. Можно предполагать, что в это время происходит миграция части населения, в первую очередь молодых мужчин. То, что это именно миграция, а не, например, гибель в результате военного столкновения, показывает факт сохранения экономического потенциала данной группы населения. Люди продолжают совершать захоронения, требующие значительного количества трудозатрат. Более того, погребение 22 достаточно уверенно относится к вождеским захоронениям: кроме ножей-кинжалов, колчанного набора наконечников стрел, псалиев, здесь присутствует каменная булава и бронзовое копье - маркеры высокого социального статуса погребенного.

Положение тела, в основном, скорченно на левом боку. Встречены особые виды погребений: в погребении 22 голова была отчленена от тела и находилась в области ладоней погребенного, который ее как бы держал. Ориентированы погребенные на север и северо-запад.

Инвентарь в целом тот же, что и в предыдущем периоде, но его количество в погребениях сокращается (рис. 4; 5). Пока только в Периоде 3 отмечена находка бронзового втульчатого копья и каменной булавы. Количество украшений также сокращается, подвески в 1,5 оборота в этот период не отмечены, только бронзовые браслеты и небольшое количество фаянсового бисера.

Из типов ножей в этот период встречены типичные общеабашевские ножи-кинжалы с намечающимся перекрестьем и ромбической пяткой черенка. Только в Период 3 встречены ножи без перекрестья с овальным лезвием и широким черенком с круглым окончанием (рис. 6) (Тип 3-1 по В.В. Ткачеву [Ткачев, 2007, с. 183-184]).

В области керамических традиций происходят следующие изменения (рис. 5; 7-10). Типичных синташтинских горшков с ребристым профилем, прямым плечом и внутренним ребром на отгибе венчика (Группа 1) в этот период становится меньше (31\% от всех сосудов). Практически столько же составляют и горшки с плавным профилем. Возрастает роль баночных сосудов (15\%). Небольшую, но устойчивую группу продолжают составлять «гибридные» горшки с прямым плечом, но без внутреннего ребра (Группа 2), (15\%). Отсутствуют миниатюрные сосудики с ребристым профилем.

Доля элемента «без орнамента» среди других элементов орнамента достигает 43\%, на практике это проявляется в том, что часть сосудов не орнаментирована, а часть имеет зоны без орнамента. Если же сосуд украшался, то практически всегда это был гребенчатый элемент (40\% от всех элементов орнамента данного периода). По-прежнему используются элементы в виде валиков (9\%), а вот шишечки в данный период не используются совсем.

На уровне узоров по-прежнему преобладают линейные (зигзаги, группы отрезков) (36\%). Однако значительно возросла доля треугольни- 


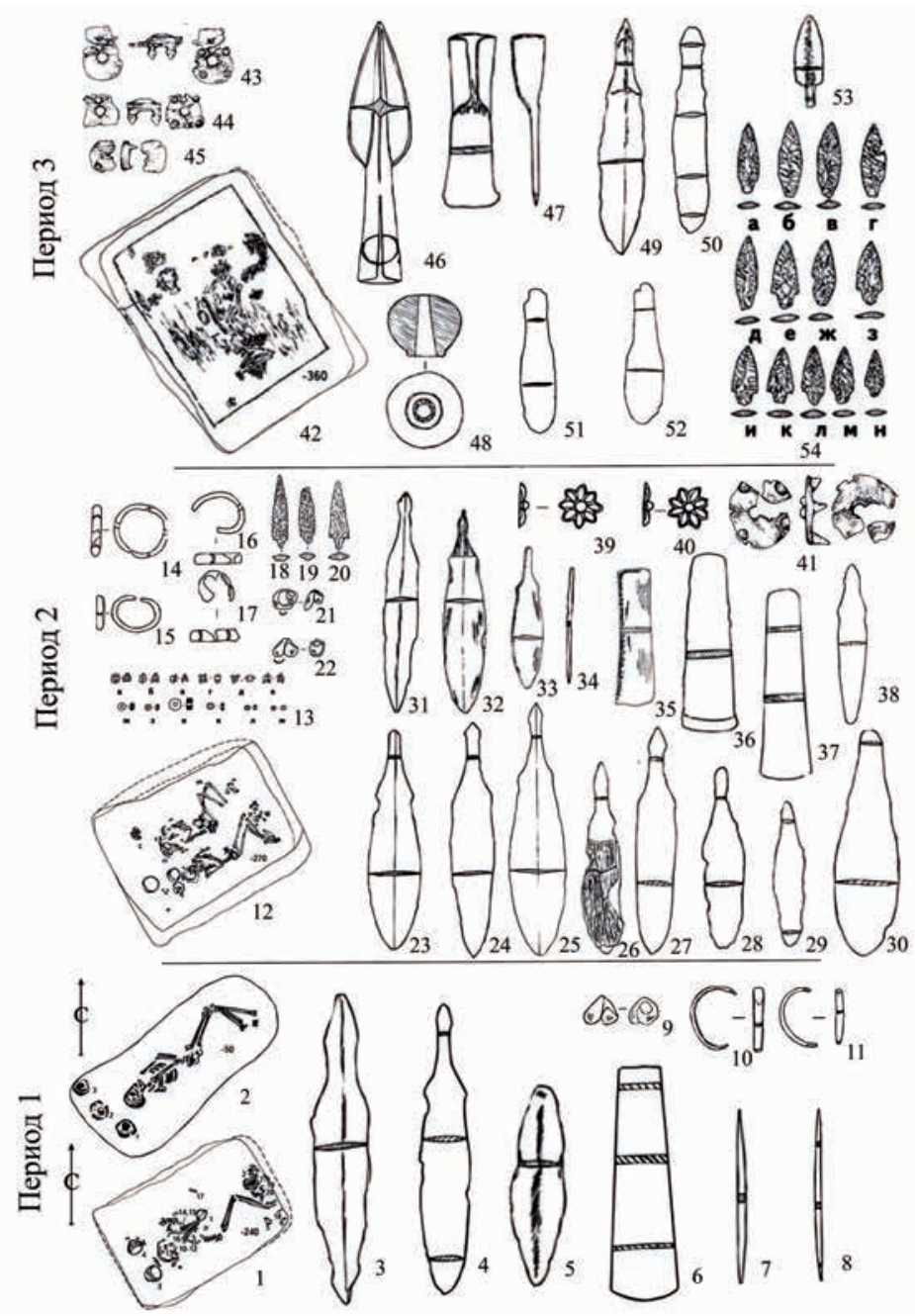

Рис. 4. Погребения и инвентарь из погребений различных хронологических периодов. 1, 3, 5, 7, 9-11-мог. Танаберген II, к. 7, n. 20; 2 -мог. Жаман-Каргала I, к. 1, n. 1; 4, 6, 8-мог. Танаберген II, к. 7, n. 25; 12, 14, 15, 27, 30, 39, 40-мог. Танаберген II, к. 7, n. 23; 13, 16, 17, 29-мог. Танаберген II, к. 7, n. 15; 18-20, 25, 28 -мог. Танаберген II, к. 7, n. 21; 21, 22, 31, 34 -мог. Танаберген II, к. 7, n. 17; 26, 37 -мог. Танаберген II, к. 7, n. 18; 23, 24, 36, 41 -мог. Танаберген II, к. 7, n. 33; 27, 30-мог. Танаберген II, к. 7, n. 23; 32, 33, 35 -мог. Жаман-Каргала I, к. 1, n. 5; 38 -мог. Танаберген II, к. 7 , n. 29; 42-49, 51, 53, 54 -мог. Танаберген II, к. 7, n. 22; 50 -мог. Танаберген II, к. 7, n. 16; 52 - мог. Танаберген II, к. 7, n. 30

Fig. 4. Burials and inventory from burials of various chronological periods. 1, 3, 5, 7, 9-11 - the burial ground Tanabergen II, kurgan 7, burial 20; 2 - burial ground of JamanKargala I, mound 1, burial 1; 4, 6, 8-the burial ground Tanabergen II, barrow 7, burial $25 ; 12,14,15,27,30,39,40$ - the burial ground Tanabergen II, barrow 7, burial 23; 13, 16, 17, 29 - burial ground Tanabergen II, barrow 7, burial 15; 18-20, 25, 28 - Tanabergen II burial ground, barrow 7, burial 21; 21, 22, 31, 34 - burial ground Tanabergen II,

barrow 7, burial 17; 26, 37 - the burial ground Tanabergen II, barrow 7, burial 18;

23, 24, 36, 41 - burial ground Tanabergen II, mound 7, burial 33; 27, 30 - the burial ground Tanabergen II, barrow 7, burial 23; 32, 33, 35 - burial ground of Jaman-Kargala I, mound 1, burial 5; 38 - burial ground Tanabergen II, mound 7, burial 29; 42-49, 51,

53, 54 - burial ground Tanabergen II, barrow 7, burial 22; 50 - Tanabergen II burial ground, mound 7, burial 16; 52 - Tanabergen II burial ground, mound 7, burial 30 


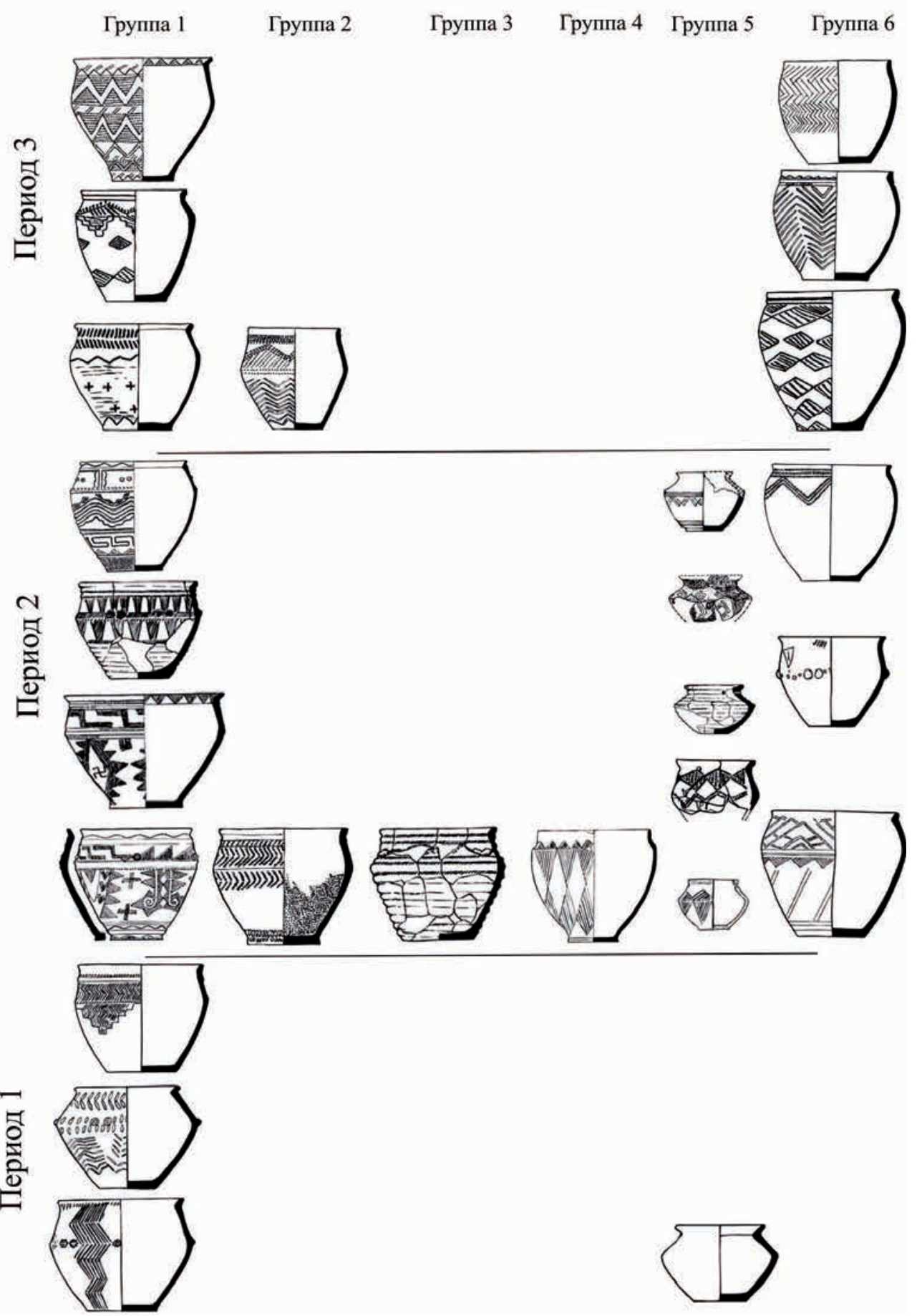

Рис. 5. Сосуды из погребений различных хронологических периодов

Fig. 5. Clay vessels from burials of various chronological periods 
Хаванский А.И. Относительная хронология и периодизация синташтинских...

\begin{tabular}{|l|c|c|c|c|c|c|}
\hline & Тип 1-1 & Тип 1-2 & Тип 1-3 & Тип 2 & Тип 3-1 & Тип 3-2 \\
\hline Период 1 & + & & & + & & \\
\hline Период 2 & + & & + & + & & + \\
\hline Период 3 & + & + & & & + & + \\
\hline
\end{tabular}

Рис. 6. Взаимовстречаемость типов ножей-кинжалов в различные хронологические периоды

Fig. 6. Interlocking types of knives-daggers in different chronological periods
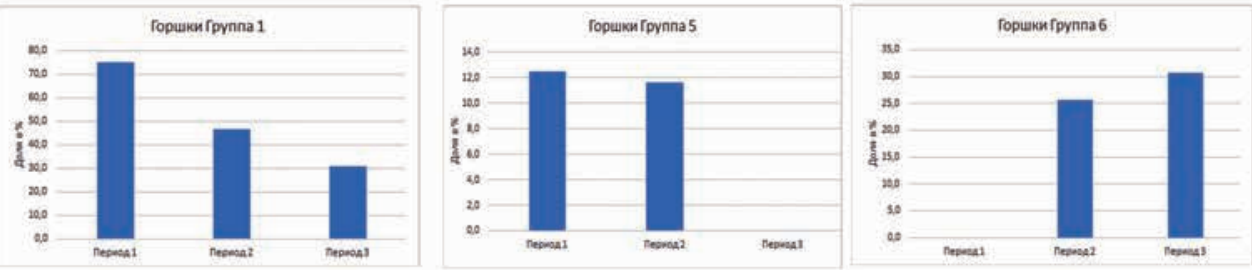

Рис. 7. Распределение основных форм глиняной посуды в различные хронологические периоды

Fig. 7. The distribution of the main forms of pottery in different chronological periods
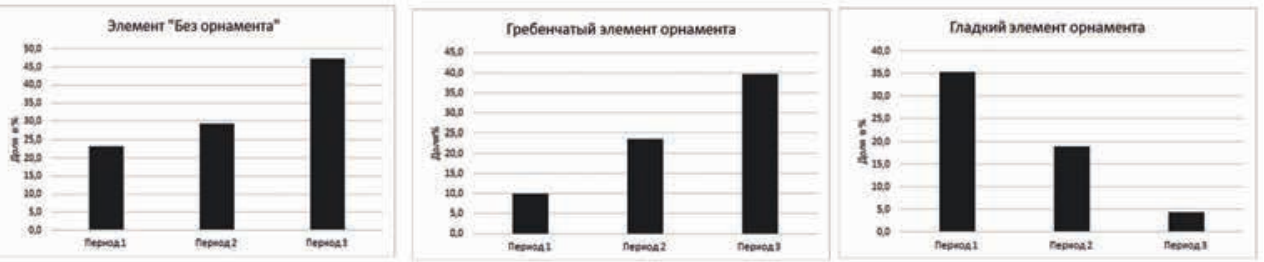

Рис. 8. Распределение основных элементов орнамента на глиняной посуде в различные хронологические периоды

Fig. 8. The distribution of the main elements of the ornament on pottery in different chronological periods 

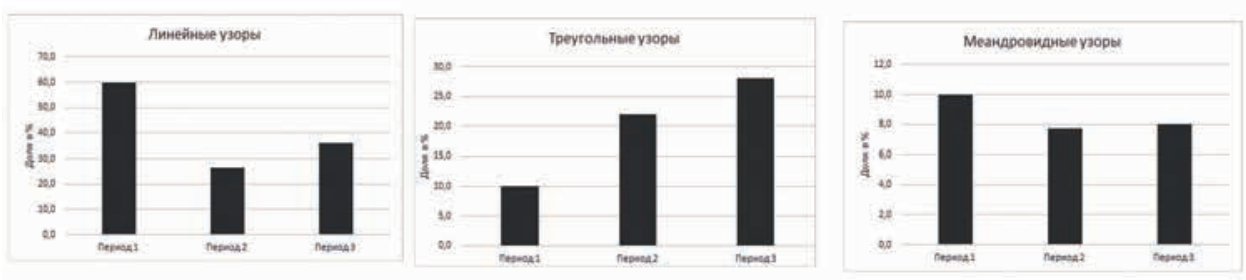

Рис. 9. Распределение основных узоров орнамента на глиняной посуде в различные хронологические периоды

Fig. 9. The distribution of the main patterns of the ornament on pottery in different chronological periods
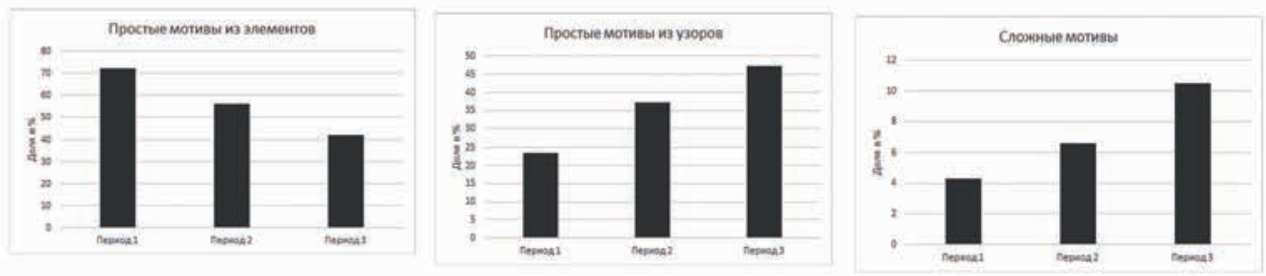

Рис. 10. Распределение мотивов орнамента на глиняной посуде в различные хронологические периоды

Fig. 10. The distribution of motifs on pottery ornament in different chronological periods

ков (28\%), а третьей по численности группой становятся узоры из лент. Однако доля ромбов и меандров остается устойчивой (по 8\%).

Мотивы из узоров (47\%) стали доминировать над мотивами из элементов (42\%). То есть в орнаментации стал преобладать «геометрический» стиль. Доля сложных мотивов, когда в одном орнаментальном бордюре чередуются разные элементы и узоры возросла до $11 \%$.

Таким образом, в данном периоде мы видим, что влияние алакульских традиций сохраняется и становится довольно существенным.

\section{Выводы}

Используя соотношение различных видов орнамента в каждом погребении (закрытом комплексе), удалось построить относительную хронологию и выявить периоды в развитии синташтинских традиций в области погребального обряда, типологии металлических изделий (прежде всего ножей-кинжалов), традиций формообразования и орнаментации керамики. Важно, что удалось выявить как долговременные тренды, так и маркеры отдельных периодов. По результатам построения относительной хронологии и периодизации синташтинских погребений Западного Казахстана в бассейне р. Илек, история этой группы населения предстает следующим образом. В Период 1 эта группа населения появляется в данном регионе и существует относи- 
Хаванский А.И. Относительная хронология и периодизация синташтинских...

тельно обособленно от других этнокультурных групп. Набор керамики, металлических изделий, украшений достаточно компактен, традиции относительно однородны. Предварительно традиции этой группы можно назвать близкими к абашевским. В Период 2 начинаются контакты с инокультурным, вероятно, с раннеалакульским (срубноалакульским?) населением. Это проявляется в появлении керамики с алакульскими чертами (горшков с вогнутым плечом (уступом), резком увеличении доли узоров из треугольников и лент, разнообразии видов женских украшений, появлении некоторых типов ножейкинжалов). В Период 3 продолжаются те же тенденции, что в Период 2. Однако, ядро синташтинских культурных традиций сохраняется на протяжении всей истории существования данной группы населения в Западном Казахстане. Культурные контакты с ранними алакульцами только ускорили развитие технологий и культурных традиций.

\section{ЛИТЕРАТУРА}

1. Бобринский А.А. Гончарство Восточной Европы. Источники и методы изучения. М.: Наука, 1978. 272 с.

2. Волкова Е.В. Гончарство фатьяновских племен. М.: Наука, 1996. 122 с.

3. Епимахов А.В. Южное Зауралье в эпоху средней бронзы. Челябинск: Изд-во ЮУрГУ, 2002. 170 с.

4. Калиева С.С., Логвин В.Н. Могильник у поселения Бестамак // ВААЭ. 2008. № 9. C. 32-58.

5. Каменеикий И.С., Узянов А.А. О правилах построения гистограмм // Археологические исследования на Урале и в Западной Сибири. Свердловск, 1977. С. 38-49.

6. Рыкушина Г.В. Антропологическая характеристика населения эпохи бронзы Южного Урала по материалам могильника Кривое Озеро // Виноградов Н.Б. Могильник бронзового века Кривое Озеро в Южном Зауралье. Челябинск: Южно-Уральское книжное издательство, 2003. С. 319-360.

7. Телегин Д.Я. Опыт статистического определения индекса родственности неолитических комплексов по элементам орнамента // Проблемы археологии Евразии и Северной Америки. М.: Наука, 1977. С. 59-64.

8. Ткачев B.B. Степи Южного Приуралья и Западного Казахстана на рубеже эпох средней и поздней бронзы. Актобе: Актюбинский областной центр истории, этнографии и археологии, 2007. $484 \mathrm{c}$.

9. Усманова Э.Р. Могильник Лисаковский I. Караганда-Лисаковск, 2005. 232 с.

10. Цетлин Ю.Б. Неолит центра Русской равнины. Орнаментация керамики и методика периодизации культур. Тула: Гриф и К, 2008. 352 с.

11. Цетлин Ю.Б. Древняя керамика. Теория и методы историко-культурного подхода. М.: ИА РАН, 2012. $384 \mathrm{c.}$

12. Хаванский А.И. Относительная хронология орнаментации керамики синташтинских могильников // РА. 2010. № 3. С. 22-36.

13. Хаванский А.И. Внутренняя хронология Синташтинского культурного комплекса // Аркаим-Синташта: древнее наследие Южного Урала: к 70-летию Г.Б. Здановича. Челябинск: изд-во Челяб. гос. ун-та, 2010. Ч. 1. С. 74-81.

14. Хаванский А.И. Возможности «керамической» хронологии // Актуальная археология 3: новые интерпретации археологических данных: тез. Междунар. научн. конф. молодых ученых (г. СПб., 25-28 апреля 2016 г). СПб.: Невская книжная типография, 2016. С. $125-129$.

15. Шевнина И.В. Логвин А.В. Могильник эпохи бронзы Халвай III в Северном Казахстане. Материалы и исследования по археологии Казахстана. Т. VII. Астана: Издательская группа филиала Института археологии им. А.Х. Маргулана, 2015. 248 с. 
Сведения об авторе:

Хаванский Алексей Иванович - кандидат исторических наук, старший научный сотрудник, Институт археологии им. А.Х. Маргулана (г. Алматы, Казахстан); Arkaim01@yandex.ru

\title{
ЕЛЕК ӨЗЕНІ БАССЕЙНДЕГІ БАТЫС ҚАЗАҚСТАНДАҒЫ СЫНТАСТЫ ЖЕРЛЕУ ЕСТЕРКІШТЕРІНІН САЛЫСТЫРМАМАЛЫ ХРОНОЛОГИЯСЫ МЕН КЕЗЕНГЕ БӨЛУ
}

\begin{abstract}
А.И. Хаванский
Мақала Елек өзеннің бассейніндегі Батыс Қазақстан Сынтасты жерлеу мәдениетіндегі құрылымдардың салыстырмалы хронологиясы мен кезеңге бөлу нәтижелері қарастырылады. Автор үш хронологиялық кезеңді бөліп алады және солардың әрқайсысына сипаттама береді. Әр бір қабірдегі (жабық кешендегі) әртүрлі өрнектердің ара салмағын пайдалана отырып салыстырмалы хронологиясын жасауға және жерлеу рәсімі саласындағы Сынтасты дәстүрдің даму кезеңдерін, металл бұйымдардың (пышақ-қанжарлар) типологиясын, керамиканың сырт пішінің қалыптасуы мен әшекейлену дәстүрін анықтауға мүмкіндік туды. Жеке кезеңдердің ұзақ мерзімді өзгеру бағыттары мен маркері анықталды. Және маркерлерін анықтау мүмкін болды. 1 Кезеңде тұрғындардың Сынтасты топтары осы аймақта пайда болғған және салыстырмалы түрде өзге этномәдени топтардан оқшаулау болған. Керамика, метал бұйымдары, әшекейлер жиынтығы жеткілікті жинақы, дәстүрлер салыстырмалы түрде біртекті болып келеді. 2 Кезеңде өзге мәдениеттермен, мүмкін ертеалакөлдік тұрғындармен байланыс басталған. Бұл алакөлдік белгідегі (ойыс иықты «кемерлі), үшбұрыштар мен таспалы өрнектердің айқын үлкеюі, әйелдер әшекейлерінің саналуандығы, пышақ-қанжар түрлерінің пайда болуы) керамиканың пайда болуынан көрінеді. 3 кезеңде 2 кезеңдегі сол үрдіс жалғасады. Батыс Қазақстандағы тұрғындардың Сынтасты тобы өмір сүрген кезеңнің өн бойында Сынтасты дәстүрдің өзегі сақталып келгендігін және ертеалакөлдіктермен мәдени байланыс технологиялар мен мәдени дәстүрлердің дамыуын жылдамдатқандығын атап өтуіміз қажет.
\end{abstract}

Түйін сөздер: археология, Сынтасты мәдениеті, кезеңдеу, жерлеу рәсімі, қанжар, керамика, ою-өрнектер, мәдени дәстүрлер

\section{RELATIVE CHRONOLOGY AND PERIODIZATION BURIALS OF SINTASHTA CULTURE OF WESTERN KAZAKHSTAN ON THE RIVER ILEK}

\section{A.I. Khavansky}

Article of the results: correcting the chronology and periodization of burials Sintashta culture of Western Kazakhstan for various types of ornament. (First of all knife-daggers). , traditions of form-building and ornamentation of ceramics. It was possible to identify both long-term trends and markers of individual periods. In Period 1 the Sintashta groups of the population appear in the given region and exist relatively apart from other ethno-cultural groups. A set of ceramics, metal products, ornaments is compact enough, traditions are relatively homogeneous. In the Period of 2, contacts with inocultural, probably, with the Early Alakul (Sorbo-Alakul?) Population begin. This is manifested in the appearance of pottery with Alakulian features (pots with a concave shoulder (ledge), a sharp increase in the proportion of patterns from triangles and ribbons, a variety of types of female jewelry, the appearance of some types of knife-daggers). In Period 3, the same trends continue as in Period 2. It should be emphasized that the core of Sintashta traditions in all earthly traditions in western Kazakhstan and cultural contacts with early Alakulians only accelerate the development of technology and cultural traditions.

Keywords: archaeology, Sintashta culture, periodization, funeral rite, daggers, ceramics, ornament, cultural traditions 


\section{REFERENCES}

1. Bobrinskiy, A. A. 1978. Goncharstvo Vostochnoy Yevropy. Istochniki $i$ metody izucheniya (Pottery Eastern Europe. Sources and Methods of Study). Moscow: "Nauka" Publ. (in Russian).

2. Volkova, Ye.V. 1996. Goncharstvo fat'yanovskikh plemen (Pottery Fatyanovo tribes). Moscow: "Nauka" Publ. (in Russian).

3. Yepimakhov, A. V. 2002. Yuzhnoye Zaural'ye v epokhu sredney bronzy (Southern Trans-Urals in the Middle Bronze Age). Chelyabinsk: South Ural State University Publ. (in Russian).

4. Kaliyeva, S. S., Logvin, V. N. 2008. In Voprosy arkheologii, antropologii i etnografii (Issues of archeology, anthropology and ethnography) (9), 32-58 (in Russian).

5. Kamenetskiy, I. S., Uzyanov, A. A. 1977. In Arkheologicheskiye issledovaniya na Urale $i v$ Zapadnoy Sibiri (Archaeological research in the Urals and in Western Siberia), 38-49 (in Russian).

6. Rykushina, G. V. 2003. In Vinogradov, N. B. Mogil'nik bronzovogo veka Krivoye Ozero v Yuzhnom Zaural'ye (Bronze Age burial ground Krivoe Ozero in the Southern TransUrals), 319-360 (in Russian).

7. Telegin, D. Ya. 1977. In Problemy arkheologii Yevrazii i Severnoy Ameriki (Problems of archeology of Eurasia and North America), Moscow: "Nauka", 59-64 (in Russian).

8. Tkachev, V. V. 2007. Stepi Yuzhnogo Priural'ya i Zapadnogo Kazakhstana na rubezhe epokh sredney i pozdney bronzy (The steppes of the Southern Urals and Western Kazakhstan at the turn of the Middle and Late Bronze eras). Aktobe: Aktyubinskiy oblastnoy tsentr istorii, etnografii i arkheologii (in Russian).

9. Usmanova, E. R. 2005. Mogil'nik Lisakovskiy I (Burial ground Lisakovsky I). Karaganda-Lisakovsk (in Russian).

10. Tsetlin, Yu. B. 2008. Neolit tsentra Russkoy ravniny. Ornamentatsiya keramiki i metodika periodizatsii kul'tur (Neolithic center of the Russian Plain. Ornamentation of ceramics and methods of cultures periodization). Tula: "Grif i K" Publ. (in Russian).

11. Tsetlin, Yu. B. 2012. Drevnyaya keramika. Teoriya i metody istoriko-kul'turnogo podkhoda (Ancient pottery. Theory and methods of historical and cultural approach). Moscow: Institute of Archaeology RAN (in Russian).

12. Khavanskiy, A. I. 2010. In Rossiyskaya arkheologiya (Russian archaeology), 3, 2236 (in Russian).

13. Khavanskiy, A. I. 2010. In Arkaim - Sintashta: drevneye naslediye Yuzhnogo Urala (Arkaim - Sintashta: the ancient heritage of the Southern Urals), 1. Chelyabinsk: Chelyabinsk State University, 74-81(in Russian).

14. Khavanskiy, A. I. 2016. In Aktual'naya arkheologiya 3: novyye interpretatsii arkheologicheskikh dannykh (Actual Archeology 3: New Interpretations of Archaeological Data). Sankt-Peterburg: Nevskaya knizhnaya tipografiya, 125-129 (in Russian).

15. Shevnina, I. V. Logvin, A. V. 2015. Mogil'nik epohi bronzy Khalvay III v Severnom Kazakhstane (The cemetery of the Bronze Age Halvay III in Northern Kazakhstan). Astana (in Kazakh, Russian, English).

\section{About the Author:}

Khavansky Alexey I. Candidate of Historical Sciences, Senior Researcher, A.Kh. Margulan Archeology Institute, Almaty, Kazakhstan; Arkaim01@yandex.ru

\footnotetext{
Мүдделер қақтығысы туралы ақпаратты ашу. Автор мүдделер қақтығысының жоқтығын мәлімдейді. / Раскрытие информации о конфликте интересов. Автор заявляет об отсутствии конфликта интересов. / Disclosure of conflict of interest information. The author claims no conflict of interest.

Мақала туралы ақпарат / Информация о статье / Information about the article. Редакцияға түсті / Поступила в редакцию / Entered the editorial office: 15.08.2018. Рецензенттер мақұлдаған / Одобрено рецензентами / Approved by reviewers: 22.08.2018. Жариялауға қабылданды / Принята к публикации / Accepted for publication: 29.10.2018.
} 